\title{
神経細胞移植におけるプレイオトロフィンの効果
}

\author{
飛 田秀 樹
}

\section{Effect of Pleiotrophin in Neural Transplantation \\ by}

Hideki Hida, M.D., Ph.D.

from

Department of Neurophysiology \& Brain Science, Nagoya City University Graduate School of Medical Sciences

Before clinical applications of neural stem/progenitor cells in neural transplantation, many basic problems need investigating; for example, how to induce the differentiation to neurons and how to improve the survival of grafted cells. Therefore, search and analysis for differentiation/survival factors are important areas of neural transplantation research.

To for search differentiation/survival factors of dopaminergic (DAergic) neurons, we investigated enhanced trophic factor in the DA-depleted striatum using ELISA and a cDNA microarray. Expression of pleiotrophin (PTN), VEGF and GDNF were enhanced in the DA-depleted striatum. To ascertain the effect of PTN on survival and differentiation of DAergic neurons, cultured DAergic neurons from E15 ventral mesencephalon and ESderived nestin positive cells were treated with PTN. Cultured DAergic neurons treated with PTN $(50 \mathrm{ng} / \mathrm{ml})$ at 1 and 3 day in vitro increased the number of $\mathrm{TH}^{-}$-positive cells at 5 day in vitro, although treatment with midkine $(50$ $\mathrm{ng} / \mathrm{ml}$ ), a family protein, did not; indicating that PTN promoted survival specific to DAergic neurons. It was found that PTN treatment to ES-derived nestin positive cells increased the number of TH-positive cells after neural differentiation, showing that PTN promoted differentiation to DAergic neurons from neural stem cells.

To ascertain the effect of PTN in neural transplantation, donor cells (E15 ventral mesencephalic tissue) were treated with PTN during cell preparation; cells were transplanted into the striatum of rat hemiparkinson model and methamphetamine-induced rotation testing was carried out until 5 weeks after transplantation. It was found that PTN treatment during cell preparation improved motor functional behavior as compared to controls, and that there were more surviving DAergic neurons in the striatum at 5 weeks after transplantation in ther PTN-treated group. The results showed that PTN treatment of donor cells promotes the recovery of disturbed motor function.

Our data indicates that PTN, an enhanced trophic factor in DA-depleted striatum, is useful as a differentiation/ survival factor for DAergic neurons in neural transplantation.

(Received July 8, 2004; accepted Apri 21, 2005)

Key words : trophic factor, Parkinson disease, stem cells

Jpn J Neurosurg（Tokyo） 14:487-492, 2005

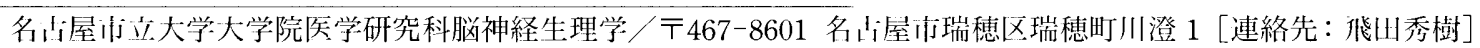

Address reprint requests to: Hideki Hida, M.D., Ph.D., Department of Neurophysiology \& Brain Science, 1 Kawasumi, Mizuho-cho, Mizuho-ku, Nagoya 467-8601, Japan 


\section{はじめに}

大脳基底核に入力した興奮性入力は, ハイパー直接路, 直接路，間接路を通じて基底核からの抑制性出力を時間 的空間的に制御し，結果的に視床や大脳皮質のニューロ ン活動を制御することによって運動を調節している。近 年，パーキンソン病における大脳基底核での病態が明ら かになってきた。すなわち，パーキンソン病では線条体 中のドパミン (DA) 量の減少に伴い, 直接路の活動低下 と間接路の元進か誘発され，その結果大脳基底核からの 抑制性出力が常に増加した状態となっている

パーキンソン病に対する治療として, L-dopa などの薬 物療法や視床破壊術や脳深部刺激法などの脳定位手術法 が行われている，さらに，新しい治療法として“神経細 胞移植”の欧米での臨床試験が進み，一定の効果が報告 されている。しかし，神経細胞移植において “ドナー細 胞不足”が大きな問題点の一つとなつている.

この問題に対し，神経幹細胞，胚性幹（ES）細胞，骨 髄間葉系細胞などの幹細胞を用いたドナー細胞の開発が

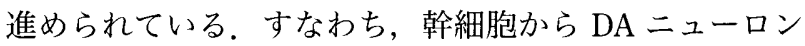
への分化誘導が可能となれば，開発されたドナー細胞を 用いた神経細胞移植の可能性が広がると考えられる，基 礎研究レベルでは，(1)幹細胞から DA ニューロンへ分化 誘導させること，(2)移植後に幹細胞由来ドナ一細胞の脳 内生着率を改善させること，などが現在のところ解決す べき問題点である。いずれの問題も，DA ニューロンの 分化誘導因子／栄養因子の探索およびその解析が重要と なってくる.

われわれは，DAが欠乏した線条体に発現増加する栄 養因子の探索，解析をこれまでに進めてきた。そ㬋補 因子の一つである pleiotrophin（PTN）の解析を進め, 神 経幹細胞および DA ニューロンに対する作用, 神経移植 における効果を検討し，以下のような結果を得たので報 告する.

\section{線条体における PTN の発現増加}

ラット胎仔（E15）中脳 DA ニューロンや中脳腹側部 由来の neurosphere を片側パーキンソン病モデルラット （6-水酸化 DA により黒質を破壊したモデル）の両側線条 体に移植すると, 移植された細胞は正常線条体内よりも $\mathrm{DA}$ を欠如した線条体内でよりよく生着, 成長する7)。こ の結果から，DA が欠如した線条体中では生体のホメオ スターシスが強く働き, 生体に有利な環境が形成され, (生体が必要としている DA の産生が可能な) DAニュー
ロンに特異的な栄養因子（分化因子，成長因子，生存因 子）の発現が増加しているのであろう，という仮説を考 えた。ホスト脳内に打ける強いホメオスターシスを示す これまでの結果として，(1DAが枯渴した線条体内に移 植された DA 細胞から産生される DA は, 3,4-dihydroxyphenyl acetic acid (DOPAC), homovanillic acid (HVA) への代謝が減少し, 線条体内の DA 量が維持されるメ力 ニズムとなっていること1)，(2)DA 細胞の移植により DA 欠乏線条体内の移植部周辺の DA レセプターの upregulation が正常化されること，などが挙げられる。

われわ机は，6-水酸化 DA の中脳黒質への投与によっ て黒質線条体路を破壊させたラットの線条体に発現増加 する栄養因子を ELISA 拈よび cDNA microarray を用い て調べた ${ }^{2)}$ 。その結果, glial cell line-derived neurotrophic factor (GDNF), FGF-2, IL-1 $\beta$ が蛋白レベルで有意に 増加していること, PTN, vascular endothelial growth factor (VEGF), glia maturation factor などの遺伝子の発現 が上昇していることを明らかにした。

成熟ラット線条体に比較的多くの mRNA 発現が認め られ，DA 入力の欠如した線条体でその発現が約 2 倍に 増加しているPTNに注目し解析を進めた．PTNに関す る報告知見として, 神経突起伸展促進作用を有する 18 $\mathrm{kDa}$ の蛋白であり，発生後期および生直後に最も高い発 現が認められる。また，発達期の側脳室周囲に発現が認 められることから発生過程での関与が考えられ，最近 PTN が神経幹細胞の分裂を抑制し分化を促進すること が示された ${ }^{3)}$.

これまでのわれわれの PTN に関する解析から，(1)DA 欠乏した線条体では, PTN レセプターの発現が増加して いる，(2)約 50\%の相同性を持つ midkine（MK）の発現 は, PTN の増加とは逆に低下している, (3)中脳由来 neurosphere 中で PTN 遺伝子の発現頻度は上位にある, な ぞの結果を得ている。 DA 欠如線条体環境下で発現増加 するPTN の作用解析の重要性が示唆されたので，(1)培 養 DA ニューロンに対するPTNの作用，(2)中脳由来 neurosphere および ES 細胞由来 nestin 陽性細胞に対す るPTN の作用, (3)神経移植における PTN の有效性につ いて解析を行った。

\section{培養 DA ニューロンへの PTN の作用}

胎生 15 日の中脳より $\mathrm{DA}$ ニューロンを調整し, 培養下 でPTN の作用を調べた ${ }^{21}$. 無処置コントロール群と比べ PTN 処置群では, 培養 5 日後にチロシン水酸化酵素 （TH）陽性細胞の数が多かった。しかし，神経マーカー 
A TH immunostaining

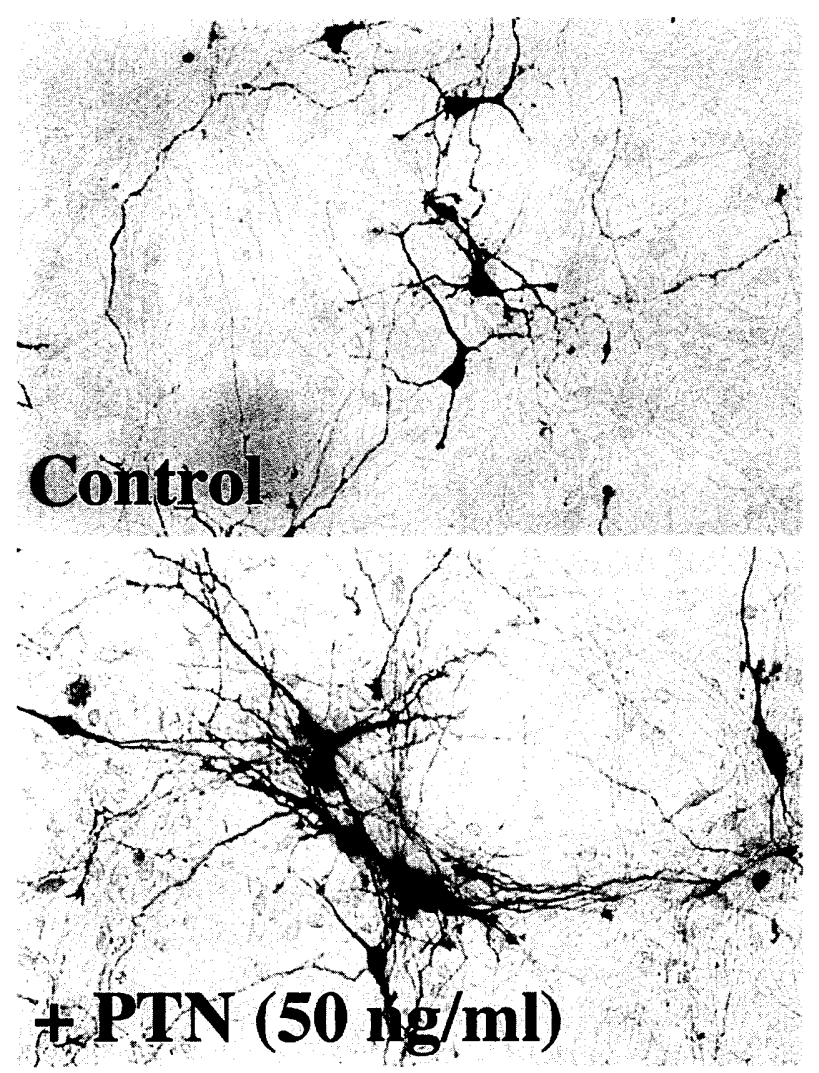

B Number of TH (+) cells

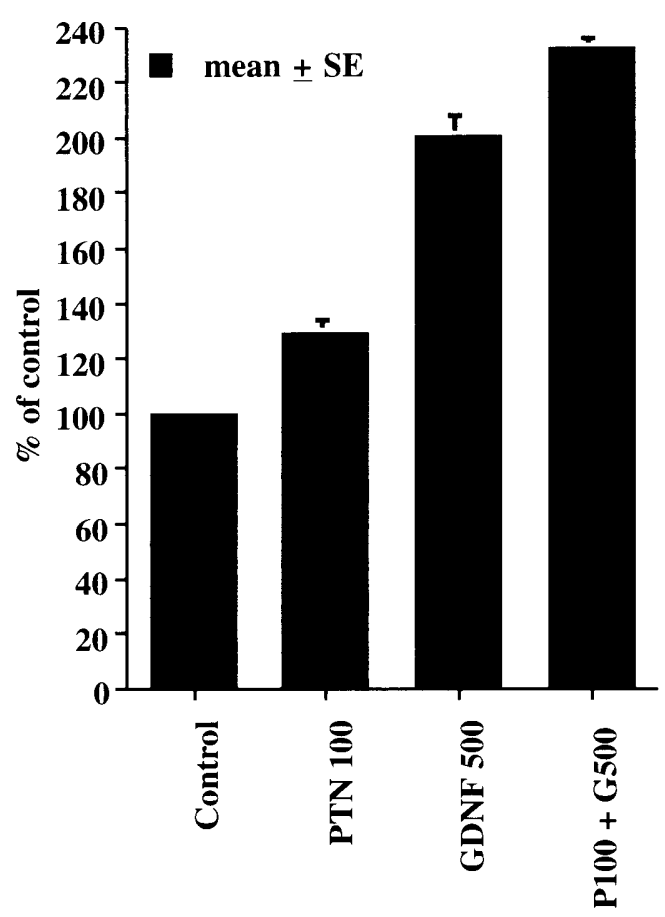

Fig. 1 PTN promotes the survival of cultured DAergic neurons

A : PTN $(50 \mathrm{ng} / \mathrm{ml})$ were added at 1 and 3 days in vitro (DIV). Cells were fixed and processed for tyrosine hydroxylase (TH) immunostaining at $5 \mathrm{DIV}$.

B : Most effective doses of PTN and GDNF were $100 \mathrm{ng} / \mathrm{ml}$ and $500 \mathrm{ng} / \mathrm{ml}$, respectively. The effect of PTN on DAergic neurons was additive to that of GDNF in vitro.

(modified from Ref 2)

の MAP-2 陽性細胞の数に違いは認められなかった。ま た，培養 5 日間（成熟したDAニューロン）にPTNを 処置した場合にも, PTN 処置群では無処置群より TH 陽 性細胞数が多かった。すなおち PTN が DAニューロンの 生存を特異的に促進することが明らかになった。一方， $\mathrm{MK}$ 処置によりこの作用は認められなかった。ささらに PTN および GDNF を最大作用濃度で同時に処置したと ころ，相加的に DA ニューロンの生存を促進することが わかった（Fig. 1)。すなおち，PTN は GDNF と異なる 機構により $\mathrm{DA}$ ニューロンの生存を促進させることがわ かった。

\section{ES 細胞由来神経幹細胞に対する PTN の作用}

PTN は発生過程で中脳背側部にも発現が認められ, $\mathrm{DA}$ ニューロン前駆細胞の分化に関与すると考えられ
る。中脳 DA ニューロン前駆細胞は, 脳室周囲から放射 状に伸びるテネシン陽性の線維上を遊走し, その後これ に直交する L1 陽性の線維上を遊走しながら DA ニュー ロンへ分化する5).この過程で sonic hedgehog (SHH) や FGF-8 が作用し，分化を誘導していると考えられて いる. 中脳背側に発現する PTN がSHH および FGF-8 とともに神経前駆細胞の分化を促進するかどうかは, 非 常に興味深い.そこで, ES 細胞由来 nestin 陽性細胞に 対する PTN の作用を調べた。すなわち, ES 細胞を 5 段 階のステップを経て神経細胞に分化誘導する系 ${ }^{6)}$ の第 4 段階の nestin 陽性細胞を増殖させる過程に, DA を欠乏 した線条体に発現増加する PTN を処置し, DA 分化誘導 が促進されるかどうかを検討した。

まず， 5 段階分化誘導法の各段階におけるPTN と

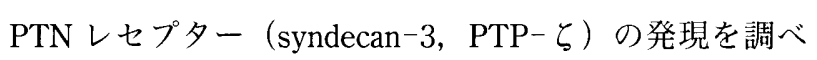
たところ, ステージ 3 すなわち ES 細胞由来 nestin 陽性 細胞のみが選別された状態から PTN と PTN レセプター 
A TH immunostaining
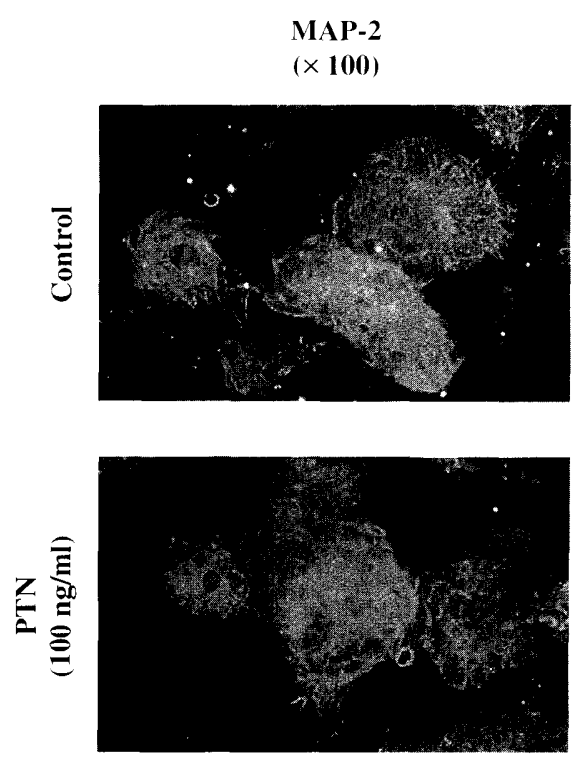
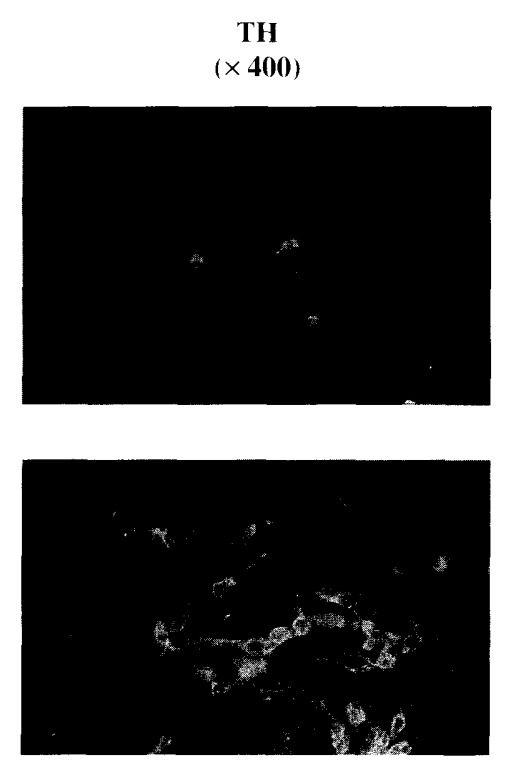

B $\quad$ TH $(+)$ cells

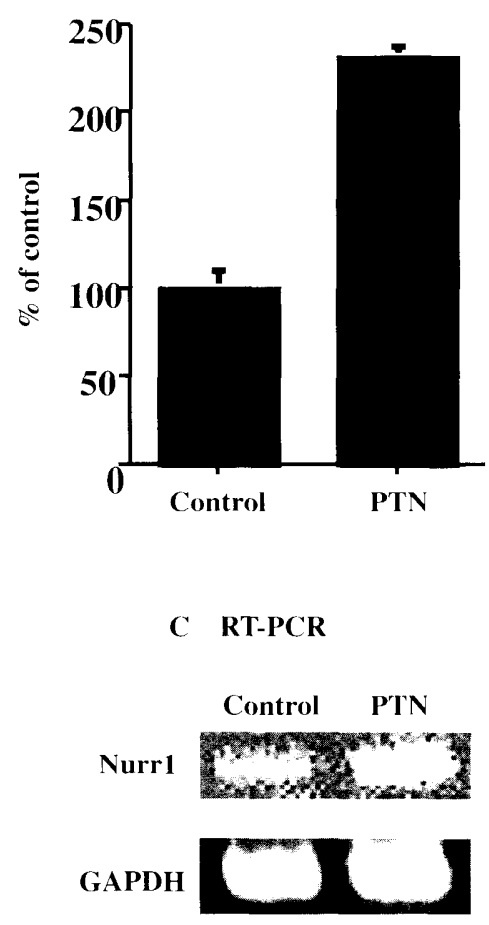

Fig. 2 PTN promotes DAergic differentiation of ES-derived nestin-positive cells

A : PTN was treated to ES-derived nestin-positive cells (stage 4) for 6-8 days. Cells were allowed to differentiate for 6 days in stage 5 and fixed at 6 days followed by MAP-2 and TH immunostaining. PTN treatment increased TH-positive cells.

B : TH-positive cells were counted. Treatment of PTN increased the number of TH-positive cells.

C : PTN addition at stage 4 induced Nurr 1 mRNA compared to control.

(modified from Ref 4)

の遺伀子が発現することがわかったＰPTNがES 細胞巾 来 nestin 陽性細胞に刘し何らかの作用を持つ可能性が わかる。 そこで，ステージ 4 の ES 細胞旪米 nestin 䎋性 細胞を bFGF 存传卜で增殖させる過程において PTN お よび SHH を作州させたところ，與処譻群に比べると約 4 倍, SHH のみの处筒群の約 2 倍の細胞が TH 陽性絒胞 に分化することを見出した（Fig. 2)。また，PTN 処置に

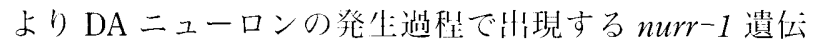
ケの発現が增加すること，堵養液中にDA が約 2 倍量分 泌されていることを確涩した。すなおち，PTNが ES 絒 胞由来 nestin 陽性絊胞の DA ニューロンへの分化唀導を 促進することが明らかになっだ!。

\section{神経移植における PTN の有効性}

わ机わ机の研究空では，照質への 6-水酸化 DA 投尗2 週後にメタンフェタミン誘炎テストを行い，1 分問に平 均 8 回転以上（>480 训㭙間）破壊倒へ回転運動を示守
動物を片側パーキンソン将モデル動物として川いてい

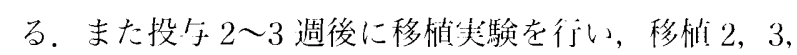

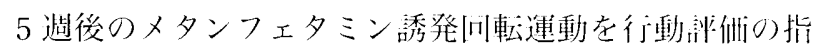
標としている。

PTNのラット（E15）中脳腹側部打米の DAニューロ ンに対する作用が in vitroで泟明されたので, 神䋂移植に

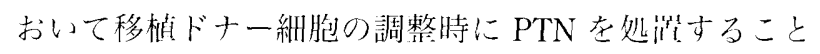
により, 運動機能の改善が促進されるかどうかを阔べた。 まず本実験目的を考慮し，E15中脎腹側部の紬織在ド

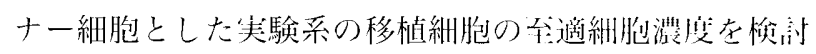

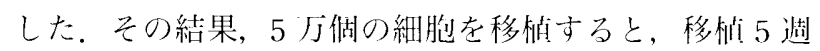

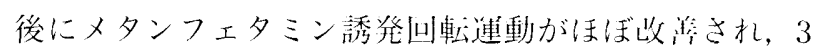
う個の細胞では軽度改善さ机る程度であることがおから

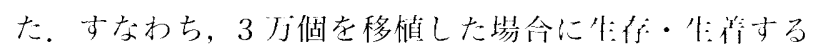
DA ニューロン（移植 5 週後にチロシン水酸化醅素陸性: 細胞数は約 134 個であった）から産生される DAに上り もたらさ机る運動機能の改善は，不完食なレベルである ことがわかる。 
A Recovery of rotation test

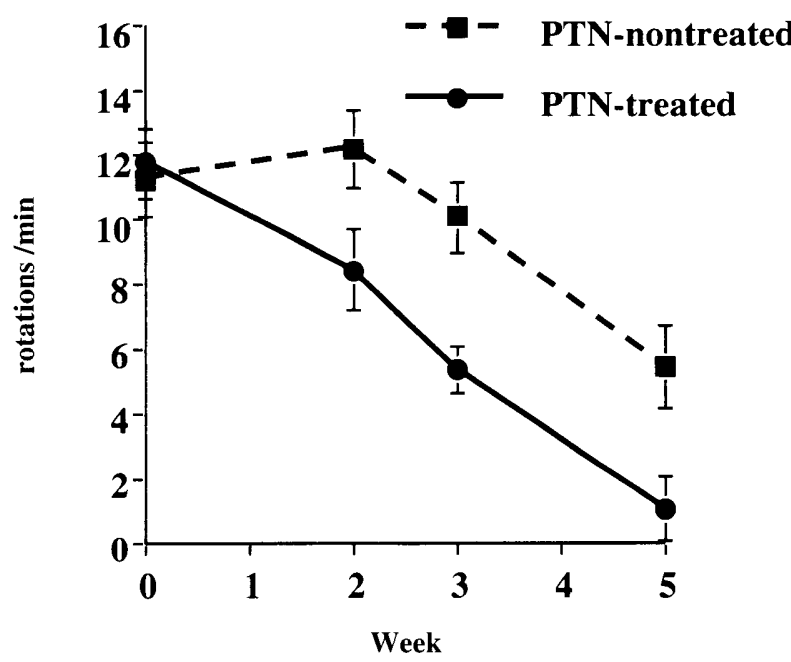

B Number of TH $(+)$ cells

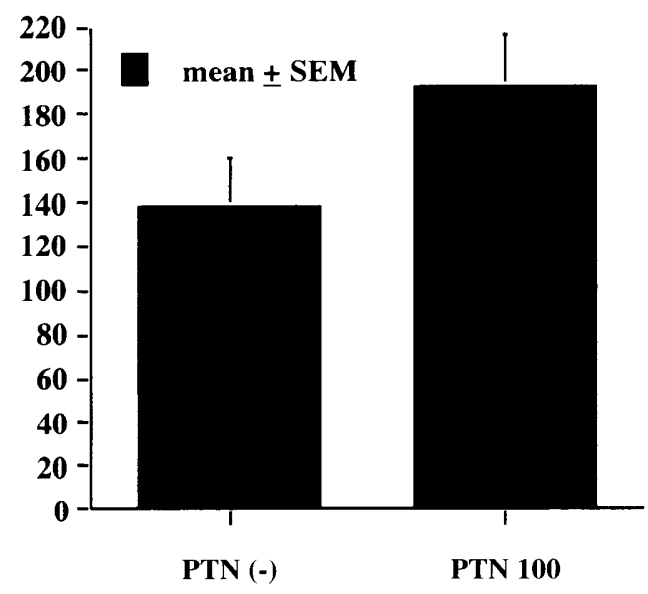

Fig. 3 Treatment of PTN during cell preparation improves functional recovery

A : Methamphetamine-induced rotation tests were carried out until 5 weeks after transplantation following PTN $(100 \mathrm{ng} / \mathrm{ml})$ treatment to E15 ventral mesencephalic tissue during cell preparation. Earlier and better functional recovery was found in PTN-treated group.

B : TH-positive cells surviving in grafted area were counted at 5 weeks after transplantation. Treatment of PTN increased the number of TH-positive cells.

そこで, 細胞調整時にPTN $(100 \mathrm{ng} / \mathrm{ml})$ を処置し 3 万個の細胞を線条体に移植したところ,コントロール無 処置群に比べ, メタンフェタミン誘発回転運動がより改 善されることがわかった（Fig. 3)。さらに，移植 5 週後 に移植部の TH 陽性細胞数を調べたところ, PTN 処置群 では陽性細胞数が約 188 個であり, 対照群の約 1.4 倍と なっていた。すなおち，細胞調整時にPTNを処置する ことにより細胞の生存が促進され，その結果運動機能の 改善が認められることが明らかになった。

\section{まとめ}

病態時に強く働く生体ホメオスターシスの解析から， 神経細胞移植において有用と考えら机る栄養因子が明ら かになった。すなわち，DAの枯渴時に線条体に発現増 加する栄養因子の 1 つである PTN が, (1)DA ニューロン の生存を特異的に促進すること, (2)ES 細胞由来 nestin 陽性細胞の DA ニューロンへの分化誘導を促進するこ と, (3)神経移植において PTN 処置がドナー細胞の in vivoでの生存を促進することが明らかになった。

\section{追記}

本文は，第 24 回日本脸神経外科コングレスにおけるプレナリー セションで発表した内容に基づきまとめたものである。

\section{研究費交付}

本研究結果は, 科学技術振興調整費 (目標達成型脳科学研究) お よび科学研究費補助金（若手 B および基盤 C）による支援のもと 行われた成果である。また, その一部は未来開拓学術推進事業によ る共同研究の成果である。

\section{文 献}

1) Hashitani T, Mizukawa K, Kumazaki M, Nishino H : Dopamine metabolism in the striatum of hemiparkinsonian model rats with dopaminergic grafts. Neurosci Res $\mathbf{3 0}$ : 43-52, 1998.

2) Hida H, Jung CG, Wu CZ, Kim HJ, Kodama Y, Masuda T, Nishino $\mathrm{H}$ : Pleiotrophin exhibites a trophic effect on survival of dopaminergic neurons in vitro. Eur J Neurosci 17: 2127-2134, 2003.

3) Hienola A, Pekkanen M, Raulo E, Vanttola P, Rauvala H: HB-GAM inhibites proliferation and enhances differentiation of neural stem cells. Mol Cell Neurosci 26:75-88, 2004.

4) Jung CG, Hida H, Nakahira K, Ikenaka K, Kim HJ, Nishino $\mathrm{H}$ : Pleiotrophin mRNA is highly expressed in neural stem (progenitor) cells of mouse ventral mesencephallon and the product promotes production of dopaminergic neurons from ES-derived nestin-positive cells. FASEB J 18: 1237-1239, 2004.

5) Kawano H, Ohyama K, Kawamura I, Nagatsu I : Migration of dopaminergicneurons in the embryonic mesencephalon of mice. Dev Brain Res 86, 101-113, 1995.

6) Lee SH, Lumelsky N, Studer L, Auerbach JM, McKay RD : Efficient generation of midbrain and hindbrain neurons from mouse embryonic stem cells. Nature Biotech 18: 675-679, 2000. 
7) Nishino H, Hida H, Takei N, Kumazaki M, Nakajima K, Baba H: Mesencephalic Neural stem (progenitor) cells develop to dopaminergic neurons more strongly in dopamine-depleted striatum than in intact striatum. Exp Neurol
164:209-214, 2000.

8）高草木董：大脳基底核の機能：パーキンソン病との関連 において。日本生理学会誌 $65(4 / 5): 113-129,2003$.

要旨

神経細胞移植におけるプレイオトロフィンの効果

飛田 秀樹

パーキンソン病に対する治療の新しい試みに神経細胞移植がある. 臨床試験において一定の効果が 示されているが，ドナ一細胞不足が大きな問題点となっている. 幹細胞を用いたドナ一細胞の開発が 期待されているが, ドパミン (DA) ニューロンへの分化誘導および移植細胞の生着率の改善が大きな 課題であり，分化因子／生存因子の探索と解析が重要となっている.

われわれは，DA 入力が久如した線条体に発現増加する栄養因子の 1 つとして pleiotrophin (PTN) を同定した.PTN の処置により，培養 DA ニューロンの生存が特異的に促進され，また ES 細胞由来 神経幹細胞の DA ニューロンへの分化が促進されることが明らかになった．さらに，PTN をドナ一細 胞の細胞調整時に処置すると, 移植後の生存細胞数が増加し, 運動機能が改善されることが明らかに なった．以上のことから，DA が欠そした線条体に発現増加する PTN の神経移植における有用性が示 された。

脳外誌 $14 ： 487-492,2005$ 